\title{
Phytoprotection
}

\section{Populations genetics and the evolution of herbicide resistance in weeds}

\section{Jasieniuk et B.D. Maxwell}

Volume 75, numéro 4, 1994

Herbicide Resistance Workshop - Edmonton, Alberta - 9 and 10 december 1993

Atelier sur la résistance aux herbicides - Edmonton (Alberta) - 9 et 10 décembre 1993

URI : https://id.erudit.org/iderudit/706069ar

DOI : https://doi.org/10.7202/706069ar

Aller au sommaire du numéro

Éditeur(s)

Société de protection des plantes du Québec (SPPQ)l

ISSN

0031-9511 (imprimé)

1710-1603 (numérique)

Découvrir la revue

Citer cet article

Jasieniuk, M. \& Maxwell, B. (1994). Populations genetics and the evolution of herbicide resistance in weeds. Phytoprotection, 75(4), 25-35.

https://doi.org/10.7202/706069ar
Résumé de l'article

De nombreux facteurs, incluant les mutations, la sélection, l'hérédité, le système de reproduction et le flux génique sont importants dans révolution de la résistance aux herbicides chez les mauvaises herbes. Les mutations spontanées seraient la principale source de variation génétique pouvant causer l'évolution de la résistance dans une région géographique où la résistance n'a pas été détectée auparavant. En dépit de la fréquence des mutations qui est probablement très faible, la probabilité qu'apparaisse au moins un mutant résistant dans une population sensible peut être élevée chez les espèces de mauvaises herbes qui ont une fécondité élevée et des populations importantes. Des traitements subséquents répétés, avec des herbicides ayant un même mode d'action, pourraient conduire à l'évolution rapide de populations composées en prédominance d'individus résistants. Les mutations de résistance héritées de façon dominante se propagent significativement plus rapidement que les mutations récessives chez les populations se reproduisant au hasard, mais à peu près au même rythme chez les espèces auto-fertiles. Le flux génique issu de la dispersion du pollen ou des graines des populations de mauvaises herbes résistantes peut procurer une source d'allèles de résistance à des champs sensibles adjacents ou avoisinants. Les modèles mathématiques indiquent que la pression de sélection imposée par un herbicide et la fréquence initiale du phénotype résistant influence très fortement le taux d'évolution de la résistance. Les modèles prédisent que les stratégies les plus efficaces pour gérer la résistance sont de réduire l'intensité de sélection par l'herbicide et de limiter la migration de graines résistantes aux herbicides.
Ce document est protégé par la loi sur le droit d'auteur. L'utilisation des services d’Érudit (y compris la reproduction) est assujettie à sa politique d'utilisation que vous pouvez consulter en ligne.

https://apropos.erudit.org/fr/usagers/politique-dutilisation/ 


\title{
Population genetics and the evolution of herbicide resistance in weeds
}

\author{
Marie Jasieniuk ${ }^{1}$ and Bruce D. Maxwell²
}

Received 1994-01-12; accepted 1994-07-11

\begin{abstract}
Numerous factors, including mutation, selection, inheritance, mating system, and gene flow are important in the evolution of herbicide resistance in weeds. Spontaneous gene mutation is believed to be the main source of genetic variation for resistance evolution in a geographic region in which resistance has not been detected previously. Despite mutation frequencies that are probably very low, the probability of occurrence of at least a single resistant mutant in a susceptible population may be high for weed species with high fecundities and large population sizes. Subsequent repeated treatments with herbicides having the same mode of action could lead to the rapid evolution of predominantly resistant populations. Rare dominantly inherited resistance mutations spread significantly more rapidly than recessive mutations in random mating populations, but at roughly the same rate in highly self-fertilizing species. Gene flow, through the movement of pollen or seed from resistant weed populations, may provide a source of resistance alleles to adjacent or nearby susceptible fields. Mathematical models indicate that the strength of selection imposed by a herbicide and the initial frequency of the resistant phenotype most strongly influence the rate of resistance evolution. The models predict that the most effective strategies to manage resistance are to reduce the intensity of selection by herbicide and to limit the migration of herbicide-resistant seed.
\end{abstract}

Jasieniuk, M. et B.D. Maxwell. 1994. La génétique des populations et l'évolution de la résistance aux herbicides chez les mauvaises herbes. PHYTOPROTECTION 75 (Suppl.): 25-35.

De nombreux facteurs, incluant les mutations, la sélection, I'hérédité, le système de reproduction et le flux génique sont importants dans l'évolution de la résistance aux herbicides chez les mauvaises herbes. Les mutations spontanées seraient la principale source de variation génétique pouvant causer l'évolution de la résistance dans une région géographique où la résistance n'a pas été détectée auparavant. En dépit de la fréquence des mutations qui est probablement très faible, la probabilité qu'apparaisse au moins un mutant résistant dans une population sensible peut être élevée chez les espèces de mauvaises herbes qui ont une fécondité élevée et des populations importantes. Des traitements subséquents répétés, avec des

1. Department of Plant Science, University of Manitoba, Winnipeg, Manitoba, Canada R3T 2N2. Contribution No. 961.

2. Plant and Soil Science Department, Montana State University, Bozeman, Montana, U.S.A. 59717 
herbicides ayant un même mode d'action, pourraient conduire à l'évolution rapide de populations composées en prédominance d'individus résistants. Les mutations de résistance héritées de façon dominante se propagent significativement plus rapidement que les mutations récessives chez les populations se reproduisant au hasard, mais à peu près au même rythme chez les espèces auto-fertiles. Le flux génique issu de la dispersion du pollen ou des graines des populations de mauvaises herbes résistantes peut procurer une source d'allèles de résistance à des champs sensibles adjacents ou avoisinants. Les modèles mathématiques indiquent que la pression de sélection imposée par un herbicide et la fréquence initiale du phénotype résistant influence très fortement le taux d'évolution de la résistance. Les modèles prédisent que les stratégies les plus efficaces pour gérer la résistance sont de réduire l'intensité de sélection par l'herbicide et de limiter la migration de graines résistantes aux herbicides.

\section{Nomenclature of chemical names cited in the text:}

Chlorsulfuron: 2-chloro-N-[[(4-methoxy-6-methyl-1,3,5-triazin-2-yl)amino]carbonyl] benzenesulfonamide; diclofop: ( \pm )-2-[4-(2,4-dichlorophenoxy)phenoxy]propanoic acid; trifuralin: 2,6-dinitro- $N, N$-dipropyl-4-(trifluoromethyl)benzeneamine.

\section{INTRODUCTION}

Herbicide resistance in weeds is an evolutionary phenomenon. In response to repeated treatment with highly efficaceous herbicides, weed populations change in genetic composition and become adapted to the intense selection imposed by the herbicides. Population genetics theory indicates that several factors normally influence evolutionary processes in natural populations of plants. These include mutation, selection, gene flow, mating pattern, and the inheritance of resistance. Because so many factors are involved, mathematical models have been necessary to make predictions concerning the rate of evolution of resistance and to assess strategies that delay its occurrence. The objectives of this paper are to examine the influence of numerous population genetics factors on the evolution of herbicide resistance, and the role of mathematical models in predicting the onset and dynamics of herbicide resistance in weed populations.

\section{MUTATION TO RESISTANCE}

The evolution of herbicide resistance is possible only if genetic variation for resistance exists in a weed population.
The main source of this variation in a geographic region in which resistance has not been detected previously is probably spontaneous gene mutation (Gasquez and Compoint 1981; Warwick and Marriage 1982). Rates of spontaneous gene mutation to herbicide resistance are unknown for any weed species, although a few estimates have been made in other plants. Frequencies of spontaneous acetolactate synthase (ALS) inhibitor resistance mutations in Arabidopsis thaliana (L.) Heynh. and Nicotiana tabacum L. have been estimated as $1 \times 10^{-9}$ and $2.7 \times 10^{-8}$, respectively (Harms and DiMaio 1991; Saari et al. 1994). The values are lower than the spontaneous mutation rates of $1 \times 10^{-5}$ and $1 \times 10^{-6}$ gametes per locus per generation typically observed in biological organisms (Merrell 1981). Frequencies of mutation to resistance are likely to differ among herbicide classes since mutation rates are influenced by numerous factors and vary considerably among gene loci.

The probability of a resistant mutant arising in a weed population is directly related to the size of this population. Larger populations, for example, those with high weed densities, have a higher probability of occurrence of resistant mutants than smaller populations 
(Jasieniuk et al. 1994a; Maxwell and Mortimer 1994). Resistant plants are thus more likely to appear in weed species with high fecundities than in species with lower reproductive rates, all other things being equal. The relation between the size of a weed population and the likelihood of resistant mutants may partly explain why herbicide resistance has evolved in some populations but not others. Some populations simply may not reach sufficiently high numbers for the occurrence of a resistant plant to be likely.

The frequency of resistant mutants in a weed population at the time of initial exposure to a particular herbicide is a function of the rate of mutation to resistance, the relative fitness of resistant and susceptible phenotypes, and the dominance of the resistance mutation(s) (Jasieniuk et al. 1994a). Higher rates of mutation to resistance result in higher frequencies of resistance alleles (Table 1). Initial frequencies are also greater when resistant mutants are as fit as susceptible plants in the absence of herbicide than when a resistance mutation is associated with a significant fitness cost. Finally, recessive resistance mutations attain higher frequencies at equilibrium than dominant resistance mutations. There are also a number of mutations that could result in resistance to any one or group of herbicides. The frequency of each mutation in the weed population is dependent on its mutation rate, the length of time since the mutation occurred, and its fitness advantage or disadvantage relative to other mutants with similar phenotype.

The initial frequency of resistant plants is of interest since it is directly related to the time to evolve resistance in a weed population. Consider, for instance, a random mating weed species on which a herbicide imposes a moderately intense selection (has $75 \%$ efficacy), and in which resistance to the herbicide is conferred by a single, dominant allele. A 100-fold increase in the initial frequency of resistance alleles results in a three-generation decrease in the time for the frequency of resistant

Table 1. Initial frequencies of resistance alleles estimated by the equilibrium frequencies obtained based on mutation-selection balance theory ${ }^{a}$

\begin{tabular}{|c|c|c|c|}
\hline $\begin{array}{l}\text { Mutation } \\
\text { rate }\end{array}$ & $\begin{array}{c}\text { Relative } \\
\text { fitness } \\
\text { (R:S) }\end{array}$ & $\begin{array}{l}\text { Degree of } \\
\text { dominance }\end{array}$ & $\begin{array}{c}\text { Initial } \\
\text { frequency } \\
\text { of } \mathrm{R} \text { allele }\end{array}$ \\
\hline \multirow[t]{6}{*}{$1 \times 10^{-6}$} & 0.99:1 & complete & $1.00 \times 10^{-4}$ \\
\hline & & incomplete & $1.25 \times 10^{-4}$ \\
\hline & & recessive & $1.00 \times 10^{-2}$ \\
\hline & $0.25: 1$ & complete & $1.33 \times 10^{-6}$ \\
\hline & & incomplete & $1.67 \times 10^{-6}$ \\
\hline & & recessive & $1.15 \times 10^{-3}$ \\
\hline \multirow[t]{6}{*}{$1 \times 10^{-8}$} & 0.99:1 & complete & $1.00 \times 10^{-6}$ \\
\hline & & incomplete & $1.25 \times 10^{-6}$ \\
\hline & & recessive & $1.00 \times 10^{-3}$ \\
\hline & $0.25: 1$ & complete & $1.33 \times 10^{-8}$ \\
\hline & & incomplete & $1.67 \times 10^{-8}$ \\
\hline & & recessive & $1.15 \times 10^{-4}$ \\
\hline \multirow[t]{6}{*}{$1 \times 10^{-10}$} & 0.99:1 & complete & $1.00 \times 10^{-8}$ \\
\hline & & incomplete & $1.25 \times 10^{-8}$ \\
\hline & & recessive & $1.00 \times 10^{-4}$ \\
\hline & $0.25: 1$ & complete & $1.33 \times 10^{-10}$ \\
\hline & & incomplete & $1.67 \times 10^{-10}$ \\
\hline & & recessive & $1.15 \times 10^{-5}$ \\
\hline
\end{tabular}

a Data from Jasieniuk et al. 1994a. 
plants to reach levels between 0.02 and 0.8 (Jasieniuk et al. 1994a). Initial frequencies and rates of mutation to resistance have less influence on the time to evolve resistance when herbicides exert more intense selection. A 100 -fold increase in the initial frequency of resistance alleles is equivalent to only a one-generation reduction in the time to evolve resistance to a herbicide that is $99 \%$ effective in killing susceptible weeds.

\section{GENETICS OF RESISTANCE}

Weed resistance to all classes of herbicides examined to date is conferred by major genes, i.e. genes with large phenotypic effect (Jasieniuk et al. 1994a). Moreover, in the majority of studies, resistance is determined by a single major gene locus. Two factors probably account for mutations that result in the simply inherited nature of herbicide resistance. First, many modern herbicides are highly specific and interfere with single enzymes in major metabolic pathways. Mutation of a gene encoding for a target enzyme, as a result of a single or few nucleotide changes, may sufficiently alter the specificity of a herbicide to cause a major change in sensitivity to this herbicide. Second, herbicides exert strong selection against susceptible plants in weed populations. Adaptation, in the form of herbicide resistance, is possible only if the genes encoding for resistance have a sufficiently large phenotypic effect to allow the survival of a few individuals in a single generation (Macnair 1991). Polygenic inheritance of resistance is less likely since recombination among individuals for many generations would normally be necessary to accumulate a sufficient number of additive genes to produce a phenotype that could withstand typical field application rates of herbicides (Jasieniuk et al. 1994a).

Resistance to all classes of herbicides, with the exception of the triazines, is determined by nuclear genes (Jasieniuk et al. 1994a). In contrast, triazine resistance is cytoplasmically inherited in the vast majority of weed species. The mutation that confers triazine resistance involves a single base substitution in the psbA chloroplast gene, which codes for a Photosystem II membrane protein to which triazine binds (Hirschberg and Mclntosh 1983; Hirschberg et al. 1984). The sole exception to the cytoplasmic inheritance of triazine resistance is Abutilon theophrasti Medicus. A single partially dominant nuclear gene determines resistance in this species (Andersen and Gronwald 1987).

Nuclear inheritance of herbicide resistance is conferred by alleles that are at least partially dominant in all but two species (Jasieniuk et al. 1994a). There are good theoretical reasons why resistance may be largely determined by dominant alleles. A rare favorable mutation, such as herbicide resistance, will spread much faster in a population if it is at least partially dominant than if it is recessive, since heterozygotes express at least part of the phenotype of the homozygote under selection (Charlesworth 1992; James 1965). A rare dominant resistance allele is thus more likely to become established in a weed population following herbicide treatment than a recessive resistance allele.

\section{MATING PATTERNS OF WEEDS}

The considerably more rapid evolution of dominant favorable mutations relative to recessive mutations is a feature of randommating plant populations. In self-fertilizing populations, a favorable recessive mutation has a much higher likelihood of establishment and spread (Charlesworth 1992). By rapidly increasing the frequency of homozygotes at the expense of heterozygotes, selfing exposes recessive resistance alleles to selection by herbicide and reduces the chance of loss of a newly arisen recessive mutation (Jasieniuk et al. 1994a). In highly self-fertilizing species, therefore, recessive resistance mutations spread at roughly the same rate as dominant resistance mutations.

Recessive control of herbicide resistance has been observed in a single weed species. Trifuralin resistance in Setaria viridis (L.) Beauv. is determined 
by a single, recessive allele (Jasieniuk et al. 1994b). S. viridis is highly selffertilizing ( $>99 \%$ ) supporting the hypothesis that recessive genes conferring resistance, when they occur, will be found in selfing populations. The copious seed production of $S$. viridis (as many as 12000 seeds plant $^{-1}$ ) (Douglas et al. 1985) may have facilitated evolution of the recessive trait by rapidly increasing the frequency of trifluralin-resistant individuals in a population.

\section{SELECTION BY HERBICIDE}

By far the most important factor influencing the evolution of herbicide resistance in weed populations is selection by herbicide. Herbicides impose intense selection against susceptible plants, often causing the mortality of 95 to $99 \%$ of the susceptible weed seedlings in a field. If genetic variation for resistance is present, repeated herbicide application will normally result in a rapid increase in the frequency of resistant individuals until they come to dominate the population.

The strength of selection against susceptible individuals by a particular class of herbicides is directly related to the rate of evolution of resistance to the herbicide class (Gressel and Segel 1982; Jasieniuk et al. 1994a; Maxwell and Mortimer 1994; Maxwell et al. 1990a). In general, more intense selection results in more rapid evolution. Herbicide characteristics such as a single target site, long-term soil residual activity, and frequent and continuous applications are generally regarded to increase the selection pressure imposed by a herbicide (LeBaron and McFarland 1990).

When herbicides are rotated, selection for resistance to a particular herbicide is generally restricted to the growing seasons during which the herbicide is applied. With the exception of those herbicides having longer-term residual activity, the frequency of resistant plants is unlikely to increase more rapidly than the frequency of susceptible plants, and may even decline during the herbicide-off periods. Rotating herbicides with various cultural practices or herbicides differing in mode of action thus increases the time to evolve resistance in weed populations (Gressel and Segel 1990a, 1990b).

The degree to which herbicide rotations slow the evolution of resistance depends on the number of herbicideoff periods, the fitness differential between resistant and susceptible phenotypes during the herbicide-off periods, and the intensity of selection by a herbicide during the herbicide-on periods (Jasieniuk et al. 1994a). As the proportion of off years in a rotation increases, the number of generations required for a weed population to reach a given frequency of resistant plants also increases. The delay in the evolution of resistance is particularly evident when the herbicide applied during the on years imposes relatively weak selection ( $\leq 90 \%$ efficacy). If a herbicide exerts very strong selection during the herbicide-on seasons (> 95\% efficacy), a larger number of off periods in the rotation will be required to delay resistance. If a second herbicide is used in rotation or mixture with the herbicide applied during the on periods, the onset of resistance to the first herbicide can be delayed further (Maxwell et al. 1990b) (Fig. 1). The extent of the delay is directly related to the efficacy of the herbicides (Fig. 2). Simulations run with Maxwell's Resistance Simulation (RSIM) model (Maxwell et al. 1990a) indicated that when the efficacy of the first herbicide in a mixture was set at $98 \%$, $95 \%$ and $90 \%$, the delay in generations to $50 \%$ resistance to herbicide 1 in the mixture (relative to using herbicide 1 alone) was 6, 10 and 19 generations, respectively. However, an increase in the efficacy of the second herbicide will increase the delay in resistance evolution to the first herbicide.

A reduction in the fitness of resistant plants relative to susceptible plants during the herbicide-off periods of a rotation will also slow resistance evolution (Jasieniuk et al. 1994a; Maxwell et al. 1990a). For example, if resistant and susceptible plants have equal fitness, the relative frequency of 


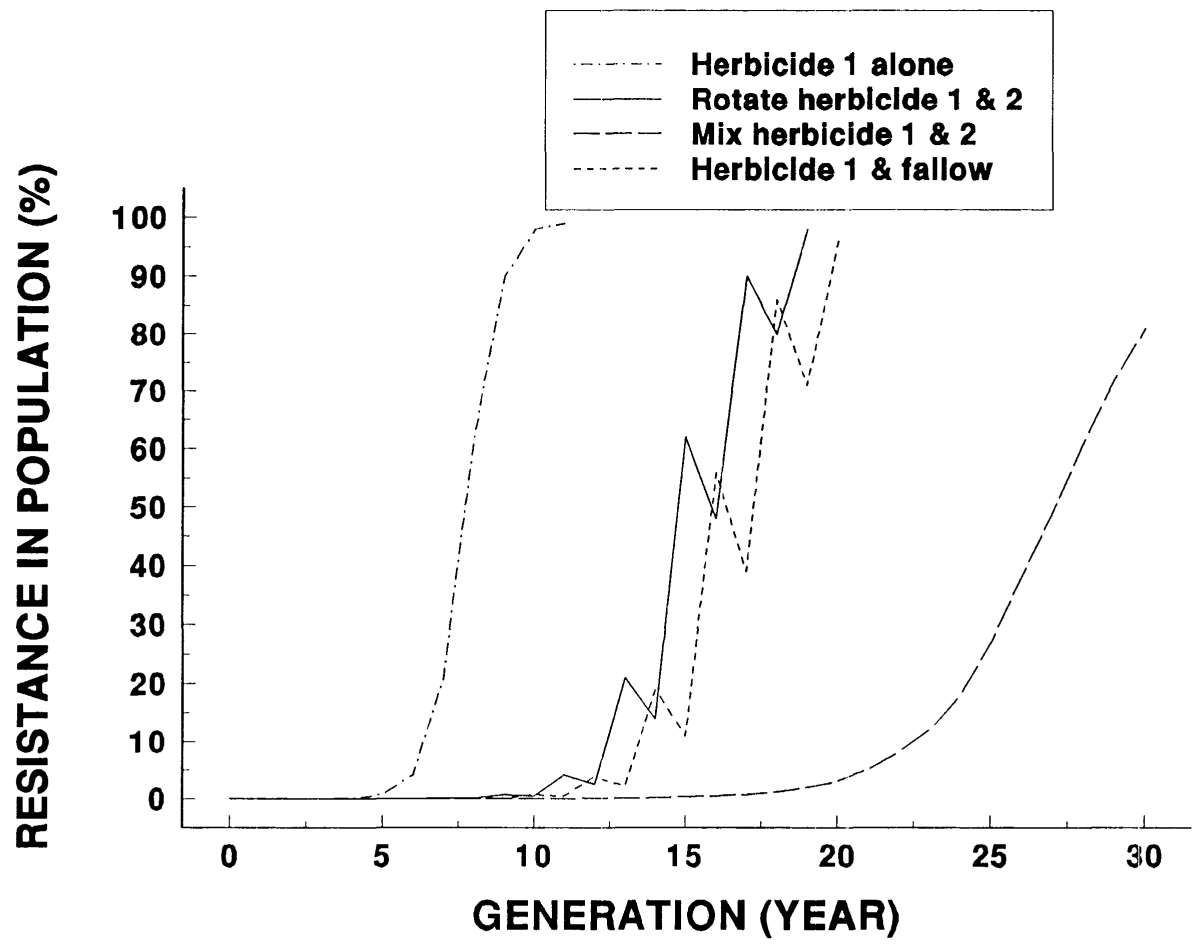

Figure 1. Simulated resistance evolution showing the percent resistance in a weed population over $\mathbf{3 0}$ generations of continuous herbicide use for four resistance management strategies, assuming an initial frequency of resistance of $1 \times 10^{-6}$. Herbicide 1 is assumed to have $90 \%$ efficacy on the susceptible phenotype, and herbicide 2 is assumed to have $80 \%$ efficacy on the susceptible and resistant phenotypes of the weed population.

resistant plants neither increases nor decreases but remains constant in the absence of herbicide treatment. In contrast, if resistant plants suffer a reduction in fitness relative to susceptible plants during the herbicide-off periods, the reduced fitness causes a decrease in their relative frequency in the absence of herbicide treatment. Thus herbicide rotations will be more effective in slowing the evolution of resistance in weed populations when a resistance mutation is associated with a cost in plant fitness. The magnitude of the fitness reduction also affects the rate at which a population returns to a predominantly susceptible state after use of a particular herbicide class is stopped (Maxwell et al. 1990a). The larger the fitness cost associated with resistance, the more rapidly will the susceptible type replace the resistant.
A drawback of using herbicide rotations and tank mixes as strategies to slow the appearance of resistance to a particular herbicide is that these tactics favour the evolution of multiple resistance, i.e. resistance to more than one herbicide differing in chemical family and mode of action. Using the RSIM model, Maxwell et al. (1990b) estimated the selection pressure for multiple resistance of several rotational and tank mix scenarios by the time to extinction of a weed population. The rate of extinction was highest for a herbicide mixture strategy and lower for a herbicide rotation strategy. If two herbicides were used in the mixture or rotation strategy, the efficacy of the second herbicide had a large impact on the intensity of selection favouring the evolution of multiple resistance. Use of a second herbicide with lower efficacy 


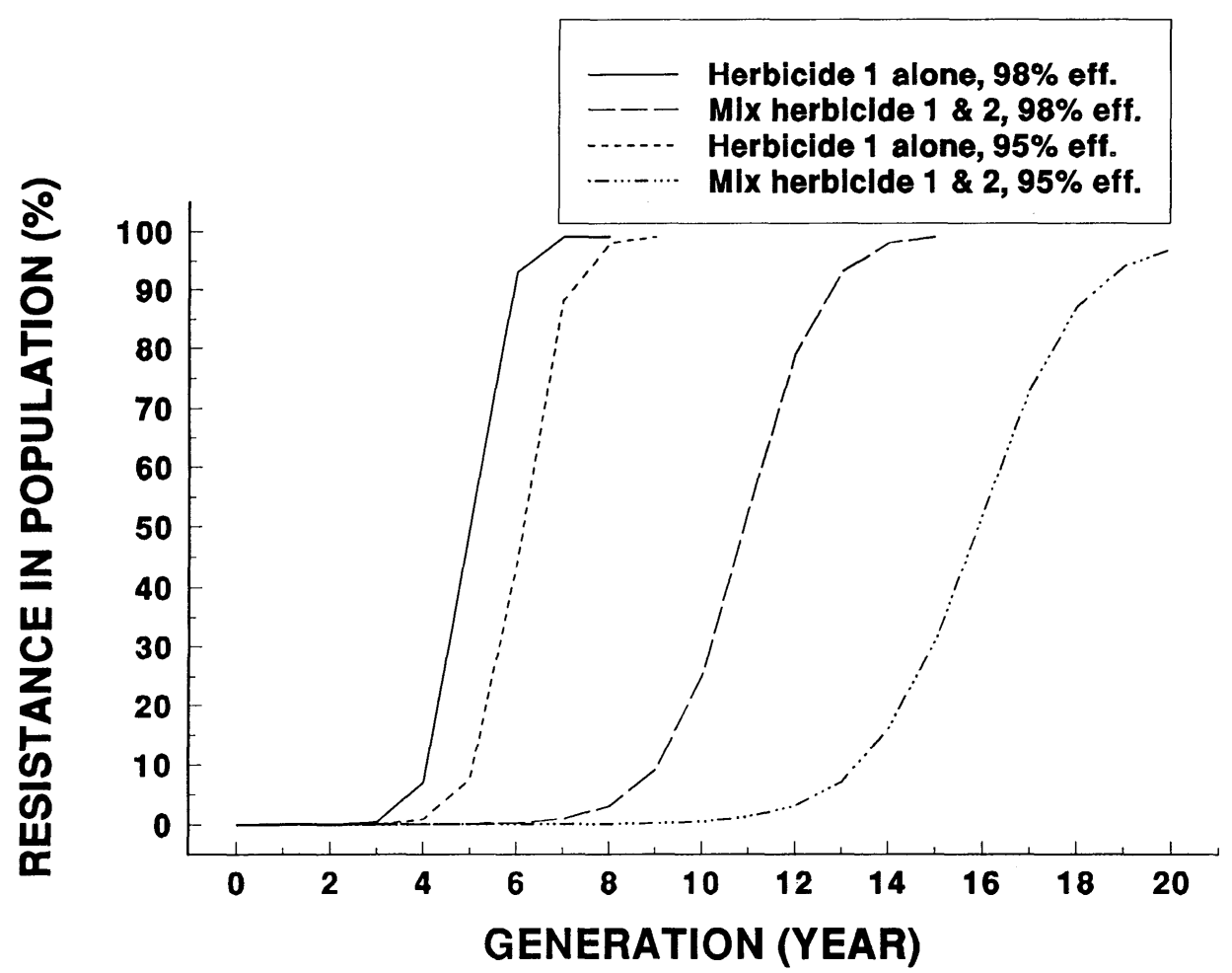

Figure 2. Influence of the efficacy of herbicide 1 on the delay of herbicide resistance evolution when using a mixture of herbicides versus herbicide 1 alone.

reduced the selection pressure for multiple resistance (Maxwell et al. 1990b).

\section{GENE FLOW AMONG POPULATIONS}

Gene flow, through the movement of pollen or seed from resistant weed populations, may provide a source of resistance alleles to adjacent or nearby susceptible fields. Rates of gene flow are distance dependent but are generally believed to be higher than rates of mutation. Thus gene flow is likely to result in a higher initial frequency of resistant plants when a particular herbicide is first applied, and resistance evolution is expected to be more rapid. In addition, if a resistance gene is introduced by the immigration of pollen or seed from nearby resistant populations, it is likely that the gene would be introduced several times and increase from several focal points. Thus the spatial distribution of resistant plants in a field would be expected to be patchy in the few generations following introduction.

Pollen dispersal has generally been assumed to be the major mechanism of gene flow among plant populations. Seed dispersal, however, may play a far greater role in weed populations. Many weed species are highly selffertilizing so that pollen flow is probably minimal. In contrast, weed seed movement due to agricultural implements can be considerable (Maxwell and Ghersa 1992; McCanny and Cavers 1988). Grain harvesting equipment, in particular, may be an important mechanism of weed seed dispersal among fields.

To date, the role of gene flow in the spread of herbicide resistance has been examined in few studies. Mulugeta et al. (1994) studied pollen dispersal from chlorsulfuron-resistant Kochia scoparia 
(L.) Schrad. plants by collecting pollen at varying distances from a pollen source population for $48-\mathrm{h}$ periods. The authors estimated that $99 \%$ of the pollen grains were deposited within $154.4 \mathrm{~m}$ of the source population. Maxwell (1992) measured effective pollen dispersion from diclofop-resistant Lolium multiflorum Lam. in the field. Resistant seeds were collected on plants $24 \mathrm{~m}$ from a $1 \mathrm{~m}^{2}$ pollen source population. Probability distributions fit to the data indicated that $99 \%$ of the expected crosses would occur within $8.6 \mathrm{~m}$ of the pollen source and that the surrounding plant canopy could cause significant changes in these distances.

The immigration of genes for susceptibility to a particular herbicide into a weed population undergoing selection by that herbicide can slow the evolution of resistance (Jasieniuk et al. 1994a; Maxwell et al. 1990a). The immigration of such genes can occur by pollen or seed dispersal from nearby susceptible populations or as a result of the germination of susceptible seed from the seed bank. The effectiveness of gene flow in opposing selection for resistance will depend on the intensity of selection by the herbicide, the inheritance of resistance, and the rate of immigration of genes for susceptibility into the weed population.

The immigration of susceptibility alleles into a weed population that is fully resistant can lead to its recovery or return to susceptibility. Two years after abandoning herbicide use, for instance, the proportion of resistant plants in a highly outcrossing weed population can be shown to decline markedly if a large population of susceptible plants is nearby and the susceptible phenotype has some fitness advantage over the resistant phenotype (Maxwell et al. 1990a; Roush et al. 1990).

The delay in evolution of resistance and the increased rate of recovery from full resistance attributable to the immigration of susceptibility alleles has led to the proposal of maintaining sources of the susceptible phenotype as a strategy to manage herbicide resistance (Maxwell et al. 1990a; Roush et al. 1990). Resistance must be conferred by a recessive allele in a highly outcrossing species, or the susceptible phenotype must be much more fit than the resistant when the herbicide is not used, for this strategy to be effective. As indicated earlier, the recessive control of resistance in outcrossing weed populations is highly improbable. Whether resistant phenotypes have markedly reduced fitness relative to susceptible phenotypes, on average, remains to be seen as data become available.

\section{MODELS OF RESISTANCE EVOLUTION}

Gressel and Segel (1978) were the first to introduce a mathematical model that integrated several of the factors discussed above and predicted the rate of appearance of herbicide resistance in weeds. Subsequent versions of the original model (Gressel and Segel 1990a, 1990b) examined the effectiveness of herbicide rotations and mixtures as strategies to delay or preclude the evolution of resistance. Maxwell et al. (1990a) developed a simulation model that examined the importance of gene flow and the relative fitness of resistant and susceptible phenotypes, as well as numerous weed management approaches, on the evolution of herbicide resistance. Putwain and Mortimer (1989) introduced a similar model to investigate strategies to manage herbicide resistance.

All of the models are based, to varying degrees, on the theories of population genetics and plant demography. A common assumption is that the weed species of interest are single cohort annuals with specific mating patterns (outcrossing or selfing) and that herbicide resistance is conferred by a single nuclear gene. A few similar predictions have been made by the models. First, the rate of resistance evolution is strongly influenced by the efficacy of the herbicide, the duration of continuous use of the herbicide, and the initial frequency of the resistant phenotype in the population. Second, the most effective strategies to manage the evolution of resistance are to reduce 


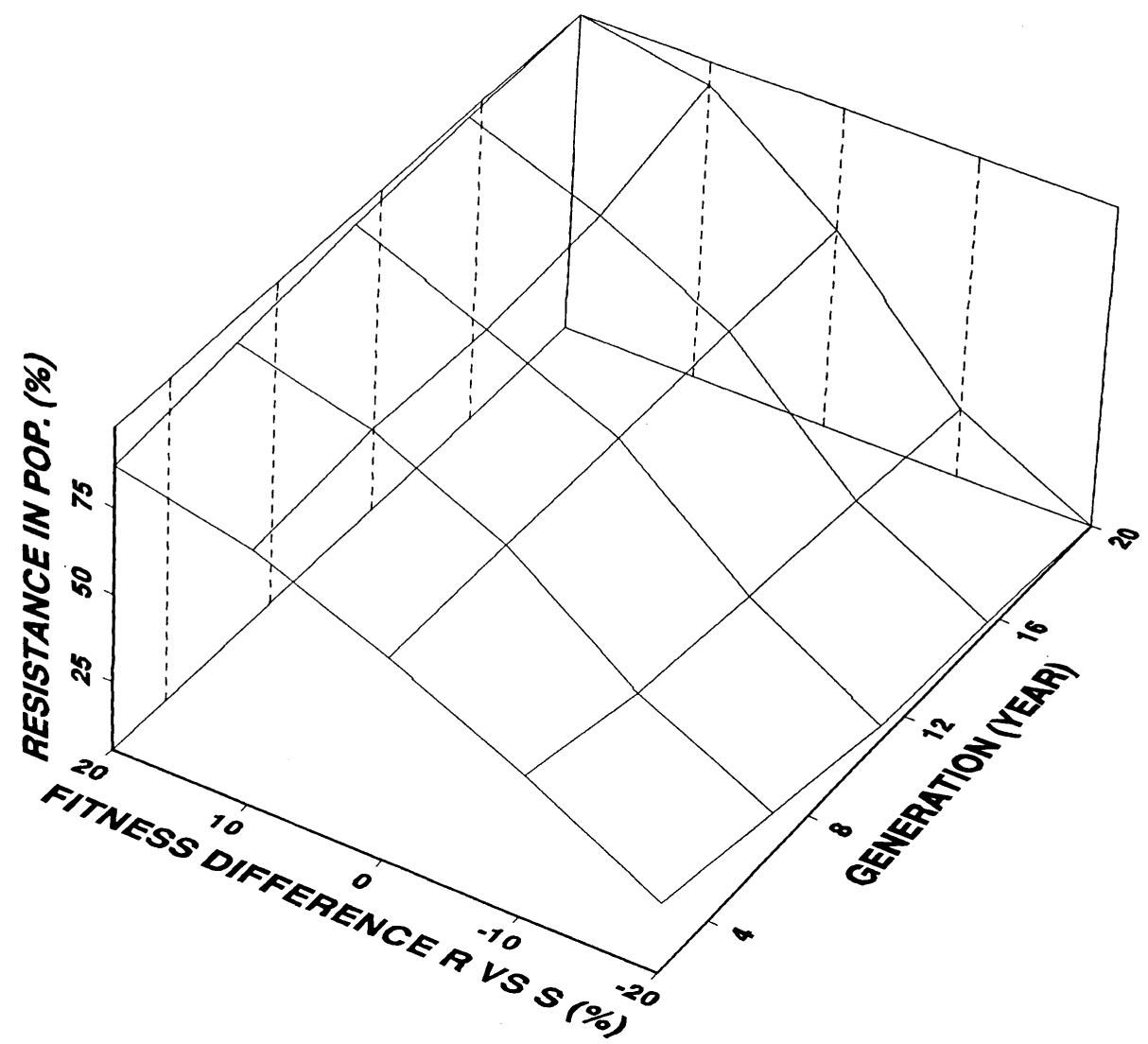

Figure 3. The frequency of resistance in a weed population after eight continuous generations of herbicide use (efficacy $=90 \%$ ) over a range of relative fitness differences between the resistant (R) and susceptible (S) phenotypes and different lengths of time (generations) between mutation to resistance and the onset of herbicide use.

the intensity of selection by herbicide and to limit the migration of herbicideresistant seed.

A major constraint to determining the accuracy of models that predict the evolution of herbicide resistance is knowing the initial frequency of resistance in populations at the onset of herbicide use. The initial frequency is dependent on the mutation rate for resistance, when the mutation for resistance occurred relative to the introduction of the herbicide, the dominance of the resistance gene, and the relative fitness of mutants with the herbicide-resistant phenotype. Simulations with the RSIM model (Maxwell et al. 1990a) were conducted to demonstrate the importance of relative fitness and time between mutation to resis- tance and the onset of herbicide use in determining the frequency of resistance after 8 generations of continuous herbicide use (Fig. 3). The difference in fitness of the resistant (R) phenotype relative to the susceptible (S) was created by increasing or decreasing the potential fecundity of the resistant phenotype by 0,10 or $20 \%$. The simulations indicated that relative fitness may have a greater impact on the initial frequency and subsequent evolution of resistance than the time between the resistance mutation and the onset of herbicide use.

In conclusion, mathematical models have been effective in elucidating the numerous interactive factors that govern the dynamics of herbicide resistance in weed populations and in 
suggesting management approaches to slow the evolution of resistance. Although none has been tested formally, predictions of the relative rates of resistance evolution correspond fairly well with field observations when the inheritance of resistance, the mating pattern of a weed species, and the demography of weed populations are known.

\section{REFERENCES}

Andersen, R.N., and J.W. Gronwald. 1987. Noncytoplasmic inheritance of atrazine tolerance in velvetleaf (Abutilon theophrasti). Weed Sci. 35: 496-498.

Charlesworth, B. 1992. Evolutionary rates in partially self-fertilizing species. Am. Nat. 140: $126-148$.

Douglas, B.J., A.G. Thomas, I.N. Morrison, and M.G. Maw. 1985. The biology of Canadian weeds. 70. Setaria viridis (L.) Beauv. Can. J. Plant Sci. 65: 669-690.

Gasquez, J., and J.-P. Compoint. 1981. Enzymatic variations in populations of Chenopodium album L. resistant and susceptible to triazines. Agroecosystem 7: 1-10.

Gressel, J., and L.A. Segel. 1978. The paucity of plants evolving genetic resistance to herbicides: possible reasons and implications. J. Theor. Biol. 75: 349-371.

Gressel, J., and L.A. Segel. 1982. Interrelating factors controlling the rate of appearance of resistance: the outlook for the future. Pages 325-347 in H.M. LeBaron and J. Gressel (eds.), Herbicide resistance in plants. John Wiley \& Sons, New York.

Gressel, J., and L.A. Segel. 1990a. Modelling the effectiveness of herbicide rotations and mixtures as strategies to delay or preclude resistance. Weed Technol. 4: 186-198.

Gressel, J., and L.A. Segel. 1990b. Herbicide rotations and mixtures: effective strategies to delay resistance. Pages 430458 in M.B. Green, H.M. LeBaron, and W.K. Moberg (eds.), Managing resistance to agrochemicals: from fundamental research to practical strategies. Am. Chem. Soc. Symp. Ser. 421, Washington, DC.

Harms, C.T., and J.J. DiMaio. 1991. Primisulfuron herbicide-resistant tobacco cell lines. Application of fluctuation test design to in vitro mutant selection with plant cells. J. Plant Physiol. 137: 513-519.

Hirschberg, J., and L. Mclntosh. 1983. Molecular basis for herbicide resistance in Amaranthus hybridus. Science (Washington DC) 22: 1346-1349.
Hirschberg, J., A. Bleecker, D.J. Kyle, L. McIntosh, and C.J. Arntzen. 1984. The molecular basis of triazine-herbicide resistance in higher-plant chloroplasts. Z. Naturforsch. 39c: 412-420.

James, J.W. 1965. Simultaneous selection for dominant and recessive mutants. Heredity 20: 142-144.

Jasieniuk, M., A.L. Brûlé-Babel, and I.N. Morrison. 1994a. The evolution and genetics of herbicide resistance in agricultural weeds. Rev. Weed Sci. (in press).

Jasieniuk, M., A.L. Brûlé-Babel, and I.N. Morrison. 1994b. Inheritance of trifluralin resistance in green foxtail (Setaria viridis). Weed Sci. 42: 123-127.

LeBaron, H.M. and J. McFarland. 1990. Herbicide resistance in weeds and crops: an overview and prognosis. Pages 336352 in M.B. Green, H.M. LeBaron, and W.K. Moberg (eds.), Managing resistance to agrochemicals: from fundamental research to practical strategies. Am. Chem. Soc. Symp. Ser. 421, Washington, DC

Macnair, M.R. 1991. Why the evolution of resistance to anthropogenic toxins normally involves major gene changes: the limits to natural selection. Genetica 84: 213-219.

Maxwell, B.D. 1992. Predicting gene flow from herbicide resistant weeds in arınual agriculture systems. Bull. Ecol. Soc. Am. 73: 264 (Abstract).

Maxwell, B.D., and C. Ghersa. 1992. The influence of weed seed dispersion versus the effect of competition on crop yield. Weed Technol. 6: 196-204.

Maxwell, B.D., and A.M. Mortimer. 1994. Selection for herbicide resistance. Fages 1-25 in S.B. Powles and J.A.M. Holtum (eds.), Herbicide resistance in plants: biology and biochemistry. Lewis Publ., Boca Raton, FL.

Maxwell, B.D., M.L. Rousch, and S.R. Radosevich. 1990a. Predicting the evolution and dynamics of herbicide resistance in weed populations. Weed Technol. 4: 2-13.

Maxwell, B.D., M.L. Rousch, and S.R. Radosevich. 1990b. Prevention and management of herbicide resistant weeds. Pages 260-267 in Proc. 9th Australian Weeds Conf. Adelaide, South Australia.

McCanny, S.J., and P.B. Cavers. 1988. Spread of proso millet (Panicum miliaceum) in Ontario, Canada. 2. Dispersal by combines. Weed Res. 28: 67-72.

Merrell, D.J. 1981. Ecological genetics. Univ. of Minnesota Press, Minneapolis, Minnesota 500 pp. 
Mulugeta, D., W.E. Dyer, B.D. Maxwell, and P.K. Fay. 1994. Kochia scoparia (L.) Schrad. pollen dispersion, viability and germination. Weed Sci. (in press).

Putwain, P.D., and A.M. Mortimer. 1989. The resistance of weeds to herbicides: rational approaches for containment of a growing problem. Proc. Brighton Crop Prot. Conf.Weeds, 1: 285-294.

Roush, M.L., S.R. Radosevich, and B.D. Maxwell. 1990. Future outlook for herbicide-resistance research. Weed Technol. 4: 208-214.
Saari, L.L., J.C. Cotterman, and D.C. Thill. 1994. Resistance to acetolactate synthase inhibiting herbicides. Pages 83-139 in S.B. Powles and J.A.M. Holtum (eds.), Herbicide resistance in plants: biology and biochemistry. Lewis Publ., Boca Raton, FL.

Warwick, S.I., and P.B. Marriage. 1982. Geographical variation in populations of Chenopodium album resistant and susceptible to atrazine. I. Between and within-population variation in growth response to atrazine. Can. J. Bot. 60: 483493. 